\title{
DUAL INOCULATION OF PISUM SATIVUM WITH RHIZOBIUM LEGUMINOSARUM AND PENICILLIUM BILAJI
}

Jim Downey and Chris van Kessel

Department of Soil Science, University of Saskatchewan, Saskatoon

\begin{abstract}
To investigate the effect of single versus dual inoculation of Trapper-pea with Rhizobium leguminosarum and Penicillium bilaji, a P solubilizing fungi, an experiment under controlled conditions was carried out using a sandy soil containing low levels of available $\mathrm{N}$ and $\mathrm{P}$. The following treatments were installed: control, $\mathrm{P}$ application at a rate of $100 \mathrm{~kg} \mathrm{P} / \mathrm{ha}$, pea inoculated with $P$. bilaji (PB50) applied at recommended rate as PB50tm supplied by Philom Bios, pea inoculated with $R$. leguminosarum $(R)$ and all possible combinations of the four treatments. To determine $\mathrm{N}_{2}$ fixation by ${ }^{15} \mathrm{~N}$-natural abundance, flax was included as the reference crop. Treatments were replicated four times and placed in a randomized complete block design. Throughout the experiment, soil was kept at $75 \%$ of field capacity and additional light was provided. After 8 weeks of growth, two plants/pot were harvested and total shoot weight, total $N$, total $P$, percent $N$ derived from $\mathrm{N}_{2}$ and the amount of $\mathrm{N}_{2}$ fixed was determined.

$\mathrm{P}$ fertilization increased yield significantly from 3.0 to $4.2 \mathrm{~g} / \mathrm{pot}$. PB50 alone increased shoot yield to $3.6 \mathrm{~g} / \mathrm{pot}$. Whereas pea inoculated with $\mathrm{R}$ showed only a small yield increase, the additional application of $\mathrm{P}$ increased yield to $4.1 \mathrm{~g} / \mathrm{pot}$. Application of $\mathrm{P}$ and both the inoculants reduced yield to $3.7 \mathrm{~g} / \mathrm{pot}$. Total $\mathrm{N}$ accumulation was highly dependent on the presence of $\mathbf{R}$. Whereas the control, which was sparsely nodulated, showed a total $N$ yield of $62.3 \mathrm{mg} \mathrm{N} / \mathrm{pot}$, inoculation with $R$ and $P$ fertilization increased total $\mathrm{N}$ to $100 \mathrm{mg} \mathrm{N} /$ pot. Double inoculation with $\mathrm{R}$ and PB50 along with $\mathrm{P}$ fertilization reduced the total $\mathrm{N}$ yield to $95 \mathrm{mg} \mathrm{N} / \mathrm{pot}$. Pea inoculated with PB50 and $\mathrm{R}$ showed a total $\mathrm{N}$ yield of $78.5 \mathrm{mg} \mathrm{N} /$ pot. The highest $\mathrm{N}_{2}$ fixing activity ( $39 \% \mathrm{Ndfa}$ or $39.6 \mathrm{mg}$ of $\mathrm{N}$ ) was observed in pea inoculated with $R$ and which had received inorganic $P$. Total $P$ uptake was solely dependent on P fertilization. Results indicate that PB50 had no beneficial influence on $\mathrm{P}$ uptake and $\mathrm{N}_{2}$-fixing activity.
\end{abstract}

\section{Introduction}

It has long been realized that soil microorganisms play an important role in organic matter decomposition and in the mineralization and release of nutrients vital for continuing plant growth. One of the important groups of microorganisms which play a role in plant nutrition are organisms which release $P$ from otherwise less available forms into a plant available nutrient. Microorganisms which impact on the $\mathrm{P}$ nutrition of plants belong to the bacteria, actinomycetes and several groups of fungi (Kucey, 1989).

Crops which often benefit the most from increased $\mathbf{P}$ availability are legumes. Legumes not only require $P$ for normal plant growth and development but also for the process of symbiotic $\mathrm{N}_{2}$ fixation. Microbially mediated $\mathrm{P}$ solubilization in the presence of $\mathrm{N}_{2}$-fixing grain legumes may be an important step to increasing yield of these important protein rich crops. 
A P-solubilizing, free-living soil fungus, $P$. bilaji has recently been isolated. This fungus has been shown to solubilize $\mathrm{P}$ in solution cultures and under greenhouse and field conditions (Asea et al., 1989; Kucey, 1987, 1988).

There remain some questions, however, regarding the process of $P$ solubilization and the increased $P$ uptake. The microorganisms would initially have to release $P$ from sources unavailable to plants and the free $\mathrm{P}$ would then have to be taken up by plants. The process of $\mathrm{P}$ solubilization from sources unavailable to plants has often been shown in artificial cultures. Tinker and Sanders (1975) however, feel that any $\mathbf{P}$ released by microbes would enter the normal adsorption equilibria of inorganic $P$ in the soil and would therefore suffer the same transport impedance as other ions.

Tinker and Sanders (1975) have also analyzed the amount of acid that would be necessary to solubilize significant amounts of inorganic $\mathrm{P}$ in bulk soil. They stated that microorganisms could not produce the needed quantities of organic acids necessary to produce the required decrease in $\mathrm{pH}$. They further stated that the plant could produce the necessary $\mathrm{pH}$ drop itself by releasing acids as exudates without the presence of microorganisms. However, Tinker's and Sander's (1975) view should be balanced with Sperber's $(1958 \mathrm{a}, \mathrm{b})$ idea that the type of acid released is probably more important to the amount of $P$ released than is the amount of acid produced. Tinker and Sanders (1975) conclude their arguments by stating that any increases in yield and $\mathrm{P}$ content of plants inoculated with microorganisms may be due more to other microbial effects such as increased efficiency of root uptake, increased root hair production and decreased rate of root senescence.

The objective of this experiment were to measure the effect of single $(R$. leguminosarum or $P$. bilaji ) versus dual inoculation ( $R$. leguminosarum and $P$. bilaji) on yield and $\mathrm{N}_{2}$ fixation by field pea.

\section{Materials and Methods}

Soil, a Shellbrook orthic dark grey Chernozemic fine sandy loam, was collected at Porcupine Plain, Saskatchewan, air dried and sieved. Soil pH measured 7.3, and $\mathrm{NO}_{3}$ and available $P$ were present in concentrations of 5.0 and $4.0 \mu \mathrm{g} / \mathrm{g}$ of soil, respectively. Pea (Pisum sativum $L_{0}$ ) was planted and the following treatments were imposed: (1) Control (no $\mathrm{P}$ added), (2) P. bilaji, (3) $R$. leguminosarum, (4) $R$. leguminosarum $+P$. bilaji, (5) $R$. leguminosarum + phosphate, (6) phosphate, (7) $P$. bilaji + phosphate, (8) $R$. leguminosarum $+P$. bilaji + phosphate, (9) flax (Linum usitatissimum L。) + phosphate. The experimental lay out was a randomized complete block design replicated four times. $\mathrm{P}$ was added at a rate of $100 \mathrm{~kg} \mathrm{P}_{2} \mathrm{O}_{5} / \mathrm{ha}$ in the form of $\mathrm{Ca}\left(\mathrm{H}_{2} \mathrm{PO}_{4}\right)_{2}$. Pots, $10 \mathrm{~cm}$ in diameter and $35 \mathrm{~cm}$ long, were placed in a greenhouse. Throughout the experiment, soil moisture was kept at $75 \%$ of field capacity. Additional artificial light was provided to assure a light intensity of $420 \mu \mathrm{E} / \mathrm{sec} / \mathrm{m}^{2}$ for $16 \mathrm{~h} /$ day. Initially, three pregerminated seeds per pot were grown, thinned to two per pot at 21 days after planting.

$\mathrm{N}_{2}$ fixation was measured by the $15 \mathrm{~N}$ natural abundance method, using flax as the non- $\mathrm{N}_{2}$-fixing reference plant (Bremer and van Kessel, 1990).

At 43 days after planting, plants were harvested, and shoot and root dried at $60^{\circ} \mathrm{C}$ until constant weight, weighed, ground to pass a sieve of $0.4 \mathrm{~mm}$, and analyzed for total $\mathbb{N}$, atom $\% 15 \mathrm{~N}$, and total $\mathrm{P}$. 


\section{Results and Discussion}

Total dry matter was affected significantly by $\mathrm{P}$ application and rhizobia (Table 1). Soil was deficient in $\mathrm{P}$ and the application of $\mathrm{P}$ fertilizer increased dry matter $35 \%$ as compared with the control. Pea inoculated with $P$. bilaji showed a significant increase in dry matter. Pea inoculated with rhizobia all showed higher total $\mathrm{N}$ accumulation as compared with uninoculated pea. The highest $\mathrm{N}$ accumulation occurred when plants were inoculated with rhizobia and $\mathrm{P}$ fertilizer was applied (Table 1). Overall, a decrease in total N occurred when $P$. bilaji was added.

Table 1. Yield, $N_{2}$ fixation and $P$ uptake by pea as affected by $R$. leguminosarum and $P$. bilaji

\begin{tabular}{|c|c|c|c|c|c|c|c|c|}
\hline Treatment & $\begin{array}{c}\text { Dry } \\
\text { matter } \\
\text { g/pot }\end{array}$ & $\begin{array}{l}\mathbb{N} \\
\%\end{array}$ & $\begin{array}{l}\text { Total N } \\
\mathrm{mg} / \mathrm{pot}\end{array}$ & $\delta^{15} \mathrm{~N}$ & $\begin{array}{c}\text { Ndta } \\
\%\end{array}$ & $\begin{array}{l}\text { Ndfa } \\
\mathrm{mg} / \mathrm{pot}\end{array}$ & $\begin{array}{l}P \\
\%\end{array}$ & $\underset{\mathrm{mg} / \mathrm{pot}}{\mathrm{P}}$ \\
\hline $\begin{array}{l}\text { Control } \\
\mathrm{P} \\
P . \text { bilaji } \\
R \text { hizobium } \\
\mathrm{P}+P \text {. bilaji } \\
\mathrm{P}+\text { Rhizobium } \\
P . \text { bilaji }+ \text { Rhizobium } \\
\mathrm{P}+P . \text { bilaji }+ \text { Rhizobium } \\
\text { Flax }\end{array}$ & $\begin{array}{l}2.97 \\
4.16 \\
3.61 \\
3.36 \\
3.89 \\
4.13 \\
2.8 \\
3.71\end{array}$ & $\begin{array}{l}2.16 \\
1.55 \\
1.89 \\
2.68 \\
1.59 \\
2.46 \\
2.81 \\
2.59\end{array}$ & $\begin{array}{r}62.3 \\
64.5 \\
68.0 \\
90.0 \\
61.4 \\
100.3 \\
78.6 \\
95.5\end{array}$ & $\begin{array}{l}6.1 \\
5.9 \\
6.3 \\
4.9 \\
6.2 \\
4.3 \\
5.2 \\
4.7 \\
6.6\end{array}$ & $\begin{array}{r}12.7 \\
12.3 \\
6.8 \\
28.4 \\
7.6 \\
39.4 \\
24.6 \\
32.4\end{array}$ & $\begin{array}{r}6.7 \\
8.0 \\
4.8 \\
25.5 \\
4.7 \\
39.6 \\
20.0 \\
30.9\end{array}$ & $\begin{array}{l}0.25 \\
0.27 \\
0.20 \\
0.20 \\
0.27 \\
0.22 \\
0.21 \\
0.23\end{array}$ & $\begin{array}{r}7.1 \\
11.1 \\
7.3 \\
6.7 \\
10.4 \\
9.1 \\
5.8 \\
8.6\end{array}$ \\
\hline LSD $(P<0.05)$ & 0.63 & 0.36 & 13.0 & 1.0 & 14.1 & 10.3 & 0.04 & 1.3 \\
\hline
\end{tabular}

As would have been anticipated, the values for $\delta^{15} \mathrm{~N}$ of inoculated pea was significantly lower than the values for $\delta^{15} \mathrm{~N}$ of uninoculated pea. The highest value, 6.6 , was found for flax. Uninoculated pea, however, showed lower $\delta^{15} \mathrm{~N}$ values than those found in flax. If no $\mathrm{N}_{2}$ fixation had occurred, the values for $\delta^{15} \mathrm{~N}$ for flax and uninoculated pea would have been similar. However, sparse nodulation of the uninoculated pea, caused by cross contamination or the presence of indigenous $R$. leguminosarum, was observed at time of harvest. The highest $\mathrm{N}_{2}$ fixing activity occurred when pea was inoculated with $R$. leguminosarum and $\mathrm{P}$ fertilizer was applied (Table 1 ). The lowest $\mathrm{N}_{2}$-fixing activity with pea uninoculated with $R$. leguminosarum. A trend was present which indicated that the addition of $P$. bilaji decreased the amount of $\mathrm{N}_{2}$ fixed. The treatments which included pea inoculated with $R$. leguminosarum ( $R$. leguminosarum plus $\mathrm{P}, \boldsymbol{R}$. leguminosarum minus $\mathrm{P}$, and the control which was sparsely nodulated) showed higher levels of $\mathrm{N}_{2}$ fixed/pot as compared with those same treatments with $P$. bilaji. However, the decrease in total $\mathrm{N}_{2}$ fixed was not significant at the $P<0.05$ probability level. 
The percentage and total $P$ accumulation was largely dependent of the application of $P$ fertilizer. The application of $P$ fertilization increased the total $P$ uptake from $7 \mathrm{mg} P /$ pot to a maximum of $11.1 \mathrm{mg} \mathrm{P} /$ pot. $P$. bilaji increased total $\mathrm{P}$ uptake in pea as compared with the control but dual inoculated pea showed lower total $\mathrm{P}$ uptake as compared with pea inoculated with $R$. leguminosarum only.

Results in this study indicate that $P$. bilaji did not increase $\mathrm{N}_{2}$ fixation or total $\mathrm{P}$ uptake. Furthermore, it appeared that $P$. bilaji showed negative effects on $\mathbb{N}_{2}$-fixing activity. One possible explanation of the averse effect of $P$. bilaji on $N_{2}$ fixation may the mode of action of the fungus. It is well reported that $\mathrm{P}$-solubilizing fungi produce organic acids which enhances the solubility of phosphate (Sperber, 1958a,b). On the other hand, most rhizobia prefer neutral or alkaline conditions for optimum performance and acid soils have a strong adverse effects on the nodulation process and $\mathrm{N}_{2}$ fixation (Lie, 1974). The production of organic acids by the fungus might have reduced the rhizophere $\mathrm{pH}$ to such a level that nodulation and $\mathrm{N}_{2}$ fixation became partially inhibited.

\section{Acknowledgements}

Financial support was provided by Saskatchewan Agriculture Development Fund. We thank L. Cowell, G. Swerhone, K. Komarnicki, and G. Parry for technical assistance and E. Farkas for her typing skills.

\section{Literature Cited}

Asea, P.E.A., Kucey, R.M.N. and Stewart, J.W.B. 1988. Inorganic phosphate solubilization by two Penicillium species in solution culture and soil. Soil Biol. Biochem. 20: 459-464.

Bremer, E., and C. van Kessel. 1990. Appraisal of the nitrogen-15 natural-abundance method for quantifying dinitrogen fixation. Soil Sci. Soc. Am. J. 54: In Press.

Kucey, R.M.N. 1983. Phosphate solubilizing bacteria and fungi in various cultivated and virgin Alberta soils. Can. J. Soil. Sci. 63: 671-678.

Kucey, R.M.N. 1987. Increased uptake by wheat and field beans inoculated with a phosphorus solubilizing Penicillium bilaji strain and with vesicular-arbuscular mycorrhizal fungi. Appl. Environ. Microbiol. 53: 2699-2703.

Kucey, R.M.N. 1988. Effect of Penicillium bilaji on the solubility and uptake of $\mathrm{P}$ and micronutrients from soil by wheat. Can. J. Soil Sci. 68: 261-270.

Kucey, R.M.N., Janzen, H.H. and Leggett, M.E. 1989. Microbially mediated increases in plant available phosphorus. Adv. Agron. 42: 199-228.

Kucey, R.M.N. and Leggett, M.E. 1989. Increased yields and phosphorus uptake by Westar canola (Brassica nopus L.) inoculated with a phosphate solubilizing isolate of Penicillium bilaji. Can. J. Soil Sci. 69: 425-432.

Lie, T.S. 1974. Environmental effects on nodulation and symbiotic nitrogen fixation. In: The Biology of Nitrogen Fixation, A. Quispel (Ed.). Nort-Holland Publishing Company. pp. 555-582.

Sperber, J.I. 1958a. Solution of apatite by soil microorganisms producing organic acids. Aust. J. Agric. Res.9:782-787.

Sperber, IJI. 1958b. The incidence of apatite solubilizing organisms in the rhizosphere and soil. Aust. J.Agric. Res. 9: 778-781.

Tinker, P.B. and Sanders, F.E. 1975. Rhizosphere microorganisms and plant nutrition. Soil Sci. 119: 363-368. 